\title{
T R A N S A C T I O N S
}

OF THE

\section{ROYAL SOCIETY OF EDINBURGH.}




\title{
T R A N S A C T I O N S
}

\author{
OF THE \\ $\begin{array}{lllllllllllll}\text { R } & \text { O } & \text { Y } & \text { A } & \text { L } & \text { S } & \text { O } & \text { C } & \text { I } & \text { E } & \text { T } & \text { Y }\end{array}$ \\ OF
}

\section{E D I N B U R G H.}

VOL. LII.

EDINBURGH :

PUBLISHED BY ROBERT GRANT \& SON, 107 PRINCES STREET, AND WILLIAMS \& NORGATE, 14 HENRIETTA STREET, COVENT GARDEN, LONDON.

MDCCCCXXI. 


\begin{tabular}{|c|c|c|c|c|c|c|c|}
\hline No. & I. & Published & February 16, 1917. & No. & XVIII. & Published & April 25, 1919 . \\
\hline ", & II. & ", & April 4, 1917 & $"$ & XIX. & $"$ & May 21, 1919 \\
\hline$"$ & III. & $"$ & May $23,1917$. & $"$ & $\mathrm{XX}$ & $"$ & May $21,1919$. \\
\hline$"$ & IV. & , & June $13,1917$. & $"$ & XXI. & $"$ & September 26,1919 . \\
\hline$"$ & $\mathrm{~V}$ & , & June 14, 1917. & $"$ & XXII. & $"$ & September 29,1919 . \\
\hline , & VI. & $"$ & June $15,1917$. & $"$ & XXIII. & , & December 22, 1919 \\
\hline$"$ & VII. & $"$ & October $5,1917$. & $"$ & XXIV. & $"$ & January 20, 1920. \\
\hline$"$, & VIII. & " & October 20,1917 & " & XXV. & , & April 2, 1920. \\
\hline " & IX. & ", & December 4, 1917. & & XXVI. & $"$ & May $11,1920$. \\
\hline$"$, & $\mathrm{X}$. & $"$ & December 4,1917 . & & XXVII. & , & June 9, 1920. \\
\hline$"$ & XI. & $"$ & February $1,1918$. & $"$ & XXVIII & $"$ & July 9, 1920. \\
\hline ", & XII. & $"$ & August 1, 1918. & $"$ & XXIX. & $"$ & March 25, 1921. \\
\hline , & XIII. & , & September 18,1918 & $"$ & XXX. & , & May 27, 1921. \\
\hline$"$ & XIV. & $"$ & September 9, 1918 & $"$ & XXXI. & , & June $21,1921$. \\
\hline$"$ & $\mathrm{XV}$ & , & October 1,1918 & $"$ & XXXII. & , & August 26, 1921. \\
\hline$"$ & XVI. & $"$ & April 15, 1919 & $"$ & XXXIII. & , & November $30,1921$. \\
\hline$"$ & XVII. & , & April 15, 1919 & & & & \\
\hline
\end{tabular}


INDEX SLIP.

Trang. R.S.E., Vol. LII, Part IV.

Gokdon, W. T.-Cambrian Organic Remains from a Dredging in the Weddell Sea : Scottish National Antarctic Expedition, 1902-1904.

Trans. Roy. Soc. Edin., vol. lii, 1920, pp. 681-714

Scottish National Antarotic Expedition, 1902-1904: Cambrian Organic Remains from the Weddell Sea.

W. T. GoRDON.

Trans. Roy. Soc. Edin., vol, lii, 1920, pp. 681-714.

Cambriau Organic Remains from the Weddell Sea: Scottish National Antarctio Expedition, 1902-1904.

W. T. GokDon

Trans. Roy. Soc. Edin., vol. lii, 1920, pp. 681-714.

Weddell Sea, Cambrian Organic Remains from : Scottish National Antaretic Expedition, 1902-1 1904 .

W. T. Gordon.

Trans. Roy. Soc. Edin., vol. lii, 1920, pp. 681-714.

Autarctic Expedition, Scottish National, 1902-1904: Cambrian Organic Remains from Weddell Sea.

W. 'T'. Gondon.

Trans. Roy. Soc. Edin., vol. lii, 1920, pp. 681-714.

Thompson, J. M'L. -New Stelar Facts, and their Bearing on Stelar Theories for the Ferns.

'l'rans. Roy. Soc. Edin., vol. lii, 1920, pp. 715-735.

Origin of Pith in Ferns.

J. M'L. Thompson.

Trans. Roy. Soe. Edin., vol. lii, 1920, pp. 715-735.

Evolution of Vascular System in Ferns.

J. M'L. Thompson.

Trans. Roy. Soc. Edin., vol. lii, 1920, pp. 715-735.

Ferns, New Stelar Facts, and their Bearing on Stelar Theories.

J. M'L. ThOM Pson.

Trans. Koy. Soe. Edin., val. lii, 1920, p!. 715-735.

Rennie, John, Philip Bruck White, and Elsis J. Harvey. -The Etiology of Isle of Wight Disease in Hive Bees.

Trans. Roy. Soc, Edin., vol. lii, 1921, pp. 737-754. 
Whrte, Philip B Bdof, - Pathology of Isle of W'ight Disease in Hive Bees. Trans. Roy. Soc. Edin., vol. lii, 1921, pp. 755-764

Harvey, Elsie J. -Experiments in Infection of Hive Bees with Tarsonemus woodi, n. sp.

Trans. Roy. Soc. Edin., vol. lii, 1921, pp. 765-767.

Tarsomemus woodi, n. sp.: Isle of Wight Disease in Hive Bees.

Elsie J. Harvey.

Trans. Roy. Soc. Edin., vol. lii, 1921, pp. 765-767.

JoHn RENNiE.

Trans. Roy. Soc. Eirin., vol. lii, 1921, pp. 768-779.

Rhenia, JoHx. - Tarsonemus waodi, n. sp.: the Causal Organism in Isle of Wight Disorse in Hive Bees.

Trans. Roy. Soc. Edin., vol. lii, 1921, pp. 768-779.

Bees, Isle of Wight Disease in Hive.

John ReNnie, P. B. Whitr, and Elsie J. HARVEY.

Trans. Roy. Soc. Edin., vol. lii, 1921, pp. 737-778.

Isle of Wight Disease in Hive Bees.

John Rennie, P. B. Whith, and Elsie J. Harvet.

Trans. Roy. Soe. Eslin., vol. lii, 1921, pp. 737-779.

Wordie, J. M.--Shackleton Antarctic Expedition, 1914-1917 : Depths and Deposits of the Weddell Sea.

Trans. Roy. Soc. Edin., vol. lii, 1921, pp. 781-793.

Shackleton Antarctic Expedition, 1914-1917: Depthis and Deposits of the Weddell Sea.

J. M. WORDIE.

Traus. Roy. Soc. Edin., vol, lii, 1921, pp. 781-793.

Weddell Sea, Depths and Deposits.

J. M. WoHDIE.

Trans. Roy. Soc. Edin., vol. lii, 1921, pp. 781-793.

Depths and Deposits of the Weddell Sea.

J. M. WORDIE,

Trans, Roy. Soc. Edin., vol. lii, 1921, pp. 781-793

Antarctic Expedition, Shackleton, 1914-1917: Depths and Deposits of Weddell Sea.

J. H. WORDIK

Trans, Roy. Soc. Edin., vol, lii, 1921, pp. 781-793.

WORDIE, J. M.-Natural History of Pack-Ice in the Weddell Sea : Shackleton Antaretic Expedition, 1914-1917.

Trans. Roy. Soc. Edin., vol. lii, 1921, pp. 795-829. 
Weddell Sea, Natural History of Pack-Ice in.

J. M. WORDie.

Trans. Roy. Suc. Edin., vol. lii, 1921, pp. 795-829.

Pack-Ice, Natural History of, in Weddell Sea.

J. M. WORDIE.

Trans. Roy. Soc. Edin., vol. lii, 1921, pp. 795-829.

Sea-Ice: Natural History of Pack-Ice in the Weddell Sea.

J. M. WORDIE.

Trans. Roy. Soc. Edin., vol. lii, 1921, pp. 795-829.

Shackleton Autarctic Expedition, 1914-1917 : Natural History of Pack-Ice.

J. M. WORDIE.

Trans. Roy. Soc. Edin., vol. lii, 1921, pp. 795-829.

Autarctic Expedition, Shackleton, 1914-1917 : The Natural History of Pack-

Ice in the Weddell Sea.

J. M. WORDIE.

Trans. Roy. Soc. Ediu,, vol. lii, 1921, pp. 795-829.

Kinston, R., and W. H. Lave.-On Old Red Sandatone Plants showing Structure, from the Rhynie Chert Bed, Aberdeenshire. Part IV. Restorations of the Vascular Cryptogams, and Discussion of their Bearing on the General Morphology of the Pteridophyta and the Origin of the Organisation of Land Plants.

Traus. Roy. Soe. Edin., vol. lii, 1921, pp. 831-854.

Rhynia Gwynne-Vaughani.

R. KidSTOx and W. H. LANG.

Trans. Roy. Soc. Edin., vol, lii, 1921, p. 832.

Rhynia major.

R. Kidston and W. H. LANG.

Trans. Roy. Soc. Edin., vol, lii, 1921, p. 835.

Hornea Lignieri.

R. Kinston and W. H. Lang.

Trans. Roy. Soc. Edin., vol, lii, 1921, p. 836.

Asteroxylon Mackiei.

R. Kidston and W. H. LANG.

Trans. Roy. Soc. Edin., vol, lii, 1921, p. 836.

Lane, W. H. See Kinston, R.

Old Red Sandstone, Plants showing Structure, Part IV.

R. KIDston and W. H. LANG.

Trans. Roy. Soc. Edin, vol. lii, 1921, pp. 831-854.

Rhynie Chert Bed, Aberdeenshire, Plants showing Structure from. Part IV. R. KIDSTON and W. H. LaNG.

Trans. Roy. Soc. Edin., vol. lii, 1921, pp. 831-854. 
KIDston, R., and W. H. LanG.-On Old Red Sandstone Plants showing Structure, from the Rhynie Chert Bed, Aberdeenshire. Part V.

The Thallophyta occurring in the Peat Bed; the Succession of the

Plants throughout a Vertical Section of the Bed; and the Conditions of Accumnlation and Preservation of the Deposit.

Trans. Roy. Soc. Edin., vol. lii, 1921, pp. 855-902.

Lang, W. H. See Kidston, R.

Thallophyta occurring in Rhynie Chert Bed, Aberdeenshire.

R. Kidston and W. H. Lang.

Trans. Roy. Soc. Edin., vol. lii, 1921, pp. 855-902.

Old Red Sandstone Plants showing Structure. Part V.

R. KIDs ron and W. H. LANG.

Trans. Roy. Soc. Edin., vol. lii, 1921, pp. 855-902.

Rhynie Chert Bed, Aberdeenshire, Plants showing Structure from. Part V. K. KIDSTON and W. H. Lane.

Trans. Roy. Soc. Fdin., vol. lii, 1921, pp. 855-902. 
The Transactions of the Royal Society of Edinborgh will in future be Sold at the following reduced Prices:-

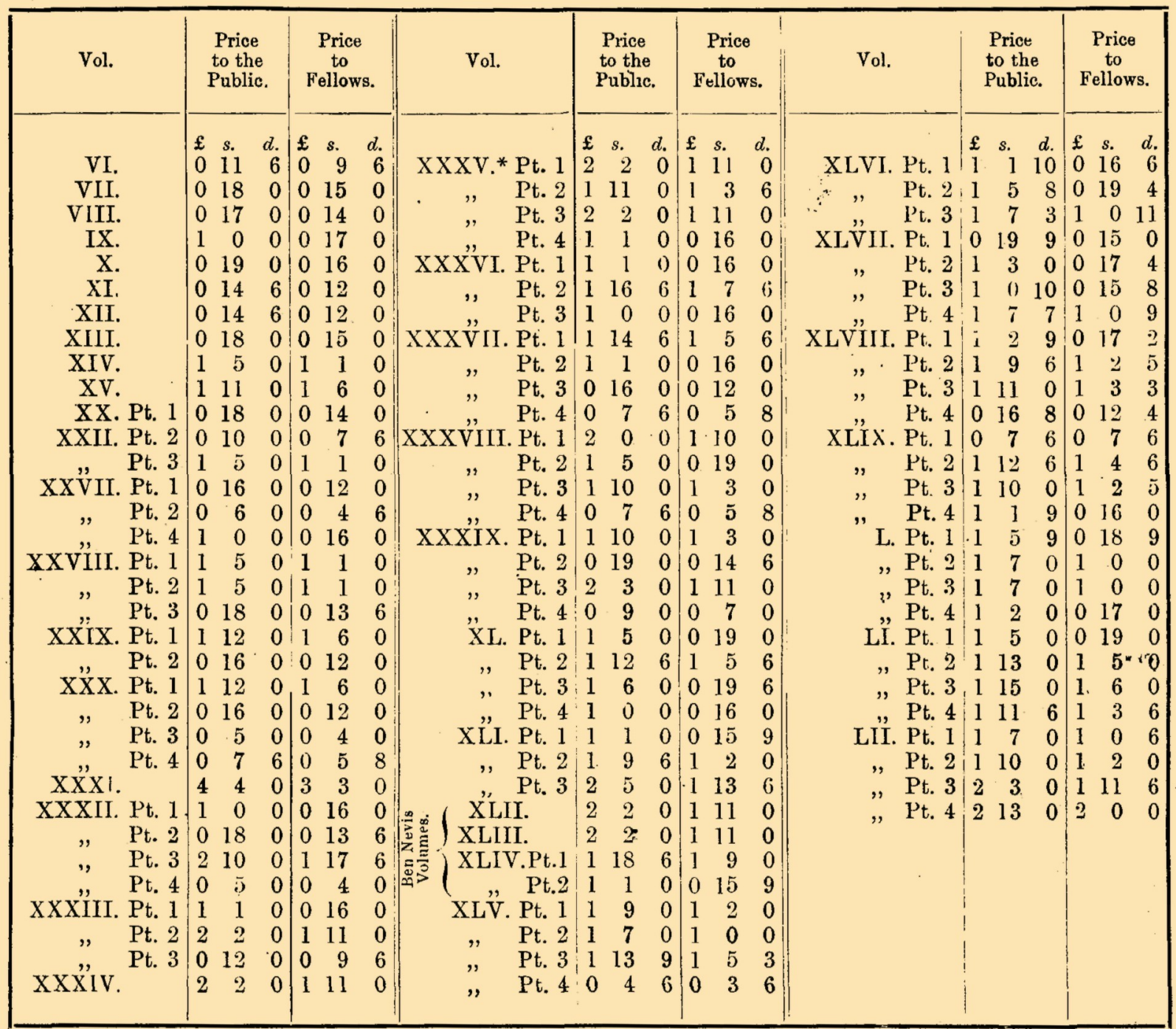

* Vol. XXXV, and those which follow, may be had in Numbers, each Number containing a complete Paper.

January 1921.-Volumes or parts of volumes not mentioned in the above list are not for the present on sale to the public. Fellows or others who may specially desire to obtain them must apply direct to the Society. As the Society reprints from time to time parts of its publications which have become scarce, the absolute correctness of this list cannot be guaranteed beyond this date.

The papers published in this Part of the Transactions may be had on application to the Pullishers, at the following prices:-

\begin{tabular}{|c|c|c|c|c|c|}
\hline & Price to Public. & Price to Fellows. & & Price to Public & Price to Fellows. \\
\hline No. XXVII, & 9s. 0d. & 7s. 0d. & No. XXXI, & 8s. 0d. & 6 s. $0 \mathrm{~d}$ \\
\hline No. XXVIII, & 5s. $6 \mathrm{~d}$. & 4s. 3d. & No. XXXII, & 6s. $6 \mathrm{~d}$. & 5s. 0d. \\
\hline No. XXIX, & 9s. $0 \mathrm{~d}$. & 6s. $9 \mathrm{~d}$. & No. XXXIII, & 13s. 0d. & 9s. 9d. \\
\hline No. $X X X,$. & - $\quad 2 \mathrm{~s} .0 \mathrm{~d}$. & 1s. $6 \mathrm{~d}$. & & & \\
\hline
\end{tabular}

